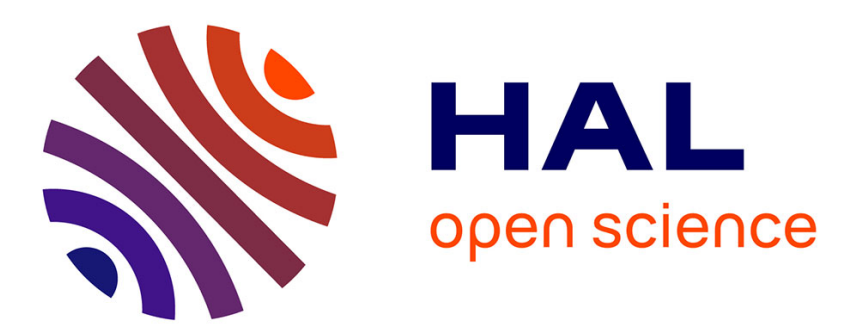

\title{
Networks of Foundations as Norm Entrepreneurs: Between Politics and Policies in EU Decision-making \\ Dorota Dakowska
}

\section{To cite this version:}

Dorota Dakowska. Networks of Foundations as Norm Entrepreneurs: Between Politics and Policies in EU Decision-making. Journal of Public Policy, 2009, 29 (2), pp.201-221. 10.1017/S0143814X0900107X . halshs-01184142

\section{HAL Id: halshs-01184142 \\ https://shs.hal.science/halshs-01184142}

Submitted on 13 Aug 2015

HAL is a multi-disciplinary open access archive for the deposit and dissemination of scientific research documents, whether they are published or not. The documents may come from teaching and research institutions in France or abroad, or from public or private research centers.
L'archive ouverte pluridisciplinaire HAL, est destinée au dépôt et à la diffusion de documents scientifiques de niveau recherche, publiés ou non, émanant des établissements d'enseignement et de recherche français ou étrangers, des laboratoires publics ou privés. 


\title{
Networks of Foundations as Norm Entrepreneurs: Between Politics and Policies in EU Decision-making
}

\author{
DOROTA DAKOWSKA Political Science, University of Strasbourg
}

\begin{abstract}
The European Commission has taken significant steps towards the recognition of political party foundations at EU level. Firstly, it has agreed to recognize them as actors of European development policies. Secondly, it has proposed the creation of political foundations at EU level, linked to the European political parties. This article analyses the reasons, modalities and potential impact of this process, which signifies a breakthrough in comparison with the Commission's previous attitude towards party affiliated organisations. For the foundations, networkbuilding turns out to have been a crucial means to attain legitimacy and access to the European institutions: firstly, through the mobilisation of political entrepreneurs in the European Parliament lobbying the Commission and Council representatives; and secondly, by linking the future role of non-state actors such as political foundations to the reconsideration of the EU's communication policy.
\end{abstract}

Key words: Party foundations, European Parliament, European Socialists, European People's Party, European Union Parties

Publicly financed foundations affiliated with political parties are a challenging research subject. ${ }^{\mathrm{T}}$ Their links to parties notwithstanding, they usually enjoy large autonomy. They develop policy ideas and contribute to agenda-setting as well as to the implementation of foreign and development policies. In Europe, the Federal Republic of Germany has the longest tradition of publicly financed associations affiliated with political parties - called political foundations - which stems from the Weimar Republic and developed especially after 1945 . In the aftermath of the Cold War, the model of political foundations spread internationally. ${ }^{2}$ With the political transformation in the Central and Eastern European Countries (CEEG) and the launch of the widest enlargement in the EU's history, European political foundations then intensified co-ordination among themselves. Many of them developed links to the emerging European political parties (previously also known 
as transnational party federations) and the political groups in the European Parliament (EP).

Despite these connections with the EP party families, the perception of political foundations has been fraught with ambiguity at EU level. While vying for support and recognition, political foundations have long since faced strong scepticism from European Commission (Commission) officials. However, owing to their mobilisation of the past several years, these organisations eventually managed to gain official recognition by the Commission, the Council and the EP on I8 December 2007, with Regulation I524/2007 revising the 2004 statute of European political parties. ${ }^{3}$ This Regulation was intended to re-evaluate the funding of European political parties, allowing them a more flexible use of EU grants and the possibility of financing transnational electoral campaigns. However, its main innovation was the provision on the establishment of 'political foundations at European level' and their financial support. Previously, in a Commission proposal issued in June 2007, European political foundations were defined as 'catalysers of new ideas' and as a means of strengthening 'informed debate on current and future European issues' (European Commission, 27 June 2007b). Moreover, the Commission expressed hope that these foundations could increase voter turnout in the 2009 EP elections. These changes mark the recognition of a new type of network at European level. Although other structures - such as youth or women's political movements - have long since been associated with the EU parties, this was the first time since the Regulation on the European political parties that the Community institutions recognised the added value of party related organisations for $\mathrm{EU}$ policy-making. ${ }^{4}$

These recent developments provide fascinating evidence of the changing relations between EU institutions and networks built around transnational party organisations. This article aims to contribute to a better understanding of this process. Until now, the two most relevant research fields have been considered separately. On the one hand, transnational political party networks are treated as an increasingly important (Hix 1995; Hix and Lord 1997) but still largely autonomous field of European policy-making (Johansson 1997; Delwit, Külahci and Van de Walle 200I). On the other, European public policies have been analysed mainly through their technical and regulatory aspects. Studies on lobbying in European governance have focused on the traditional sectors of interest representation, i.e. industrial, professional and agricultural groups (Mazey and Richardson 1993; Green Cowles I996; Saurugger 2001; Bouwen 2002; Coen 2007; Eising 2007). While the contribution of public interest groups to European policy-making has 
grown, the influence of non-governmental organisations (NGOs) appears limited by their lack of resources (Dür and De Bièvre 2007). The position of political party-affiliated foundations at EU level is distinctive, however, as they do not fit into any category of what has been termed the 'European civil society' (Weisbein 2003). The analysis of political foundations' networks at EU level calls for further investigation of the nexus between the party political and regulatory dimensions, where European politics and policies interact.

This article's guiding research question concerns the conditions for the transnational constitution and supranational recognition of a novel type of network of foundations called the European political foundations. In other words, why did the Commission - originally reluctant to finance party affiliated organisations - become converted to supporting the EP's pledges to set up European party foundations? To answer this question the article analyses the inter-institutional process leading to the 2007 Regulation. It further investigates the mobilisation of leading members of the EP (MEPs) and European federalists, which had previously contributed to the institutionalisation of Europarties (cf. Johansson and Raunio 2005). While the process could be analysed in terms of inter-institutional bargaining, i.e. the Commission accepting the EP's demands to better confront the EU Council, this explanation is not sufficient. Rather, this article shows that the establishment of political foundations at the EU level was due to the convergence of agents sharing similar beliefs and to political momentum stemming from the rethinking of EU communication policy. Crucially, transnational network-building among national foundations turns out to have been a necessary precondition for supranational institutionalisation and a means to attain legitimacy at the EU level.

Studies of European governance have highlighted the role of networks as a main feature of non-hierarchical steering between state and non-state actors at different levels (Kohler-Koch and Eising i999; see also Börzel and Heard-Lauréote in this issue). By looking at the impact of transnational (policy) networks, public policy analyses focus on the study of policy outcome, on 'bargaining' and 'problem-solving' (Pappi and Henning I998; Mayntz I993). In the process, these studies often fail to explain the dynamics of political configurations, resources and opportunities, which enable the network members to impose their view. Rarely is the question asked as to how a given network was formed (however, Kaiser in this issue gives some historical examples). In his critical reassessment of policy network analysis, Rhodes (2003: 399) called for a more empirically-grounded, qualitative approach to networks, which would 'put people back' in. More recently, he developed a 'decentred, actor-focused analysis of the games people play 
in the network' centred on beliefs and practices of agents, shaped by traditions (Rhodes 2007: I249).

Without engaging in an ethnographic 'thick description', as suggested by Rhodes, this article adopts a sociological-constructivist approach insofar as it acknowledges that networks are made up of individuals embedded in specific social, institutional and historical contexts. Focusing on agents' competing beliefs and preferences, it claims that non-hierarchical and horizontal relationships do not exclude contest and domination. Thus, networks are usually embedded in broader fields in which agents struggle for the imposition of the legitimate vision of the social world (Bourdieu i98I). Opting for an actor-centred approach, the article takes into account institutions, acknowledging that both are mutually constitutive (DiMaggio and Powell I99I; Hall and Taylor i996, Mayntz and Scharpf 200i). In examining the paradoxical case of political foundations in European governance, the article goes beyond the approach of networks as problem-solving devices, arguing that a network may be analysed both as an expression of power relations between agents and as an organisational resource in tune with the current expectations of European institutions.

In this context, I ask whether the creation of political foundations at the European level may be considered as a case of lesson-drawing (Rose I99I, I993) or policy transfer (Dolowitz and Marsh I996, 2000) from the national level, the German model being the main reference. According to Radaelli (2000), the EU's institutional context facilitates policy transfer, in the form of mimetic isomorphism. Highlighting the political context and actor configuration at the origin of European political foundations, this article leads to the conclusion that policy transfer has taken place, albeit one constrained by the existing institutional and legislative framework.

The article is divided in the following way. The first section synthesises the involvement of national political foundations and their networks in the enlargement of European party families in the r99os, and highlights the specificities of the German case. The second section investigates the modalities of political party-affiliated foundations' access to the Commission, as well as the dynamics of opening and closing of competing foundation networks. The third section analyses the actors' configurations in the European Parliament (EP), the Commission and the Council, leading to the creation of European political foundations. The fourth section deals with the effective setting up of the European political foundations as a case of constrained policy transfer. Finally, the conclusion offers a critical assessment of the recognition of political party think tanks for European governance. The 
article is based on recent empirical data, mainly qualitative, semistructured interviews and documents produced by the European institutions, the political foundations and their networks. ${ }^{5}$

Foundation Networking in the Context of the EU Enlargement: the Logic of Access

The creation of multiple political foundations across Europe in the early I990s and their role in democracy promotion in East Central Europe was a crucial precondition for the most recent European level cooperation among these organisations. As the term 'network' has become a buzz-word in the European public sphere, the political foundations have joined in this trend insisting on 'networks' as a basic form of their organisation. Most of the European party foundations, left and right, were set up after the fall of the communist regimes in the CEEG (cf. Dakowska 2009). The networking activities of these organizations were enhanced in the context of the EU's Eastern enlargement. The dissolution of the Soviet Bloc had led European political parties to search for potential partners among the emerging political families of the CEEG (De Waele and Delwit I998). After the formal launch of the enlargement process the European transnational party federations delegated a number of tasks to the political foundations. However the networks of foundations turned out to be very heterogeneous, as far as their financial means, organisational form and the nature of their party political ties were concerned.

The German political foundations are interesting case studies for the analysis of transnational networks and informal politics in Europe. Their involvement in the transnational promotion of democracy and their resources are unparalleled in most other European foundations. They occupy a strategic position between the political party and administrative fields in Germany, and have long been involved with the federal foreign and development policies (Ortuño Anaya 2002; PintoDuschinsky I996; Wagner I994). Furthermore, in the CEEC, the foundations have accumulated and developed considerable political contacts abroad, notably during the transition and reform process (Bartsch I998; Dakowska 2005a, b; Phillips I999). In particular, the transnational party networks around the EP are familiar territory for the political foundations. Because of their personal contacts in European party federations, in which the German political parties have a strong position, the field representatives of the German foundations were able to influence the admission process of CEEG parties in an informal way (Dakowska 2005b).

Facing the development of the foundations' international activities and the budgetary restrictions at the domestic level, a growing number 
of foundations vied to be recognised by the Commission. The German foundations took the lead in this mobilisation, insisting on their expertise and experience of development co-operation. However, the task proved to be a difficult one. The Commission officials were reluctant to recognise the political foundations as legitimate partners and allow them to benefit from EU funds because of their party affiliation and their national profile. Marked by a 'political culture of compromise' (Abélès and Bellier I996: 432), the Commission seeks to be perceived as an institution independent from national and political influences (Joana and Smith 2002; Smith 2004).

Consequently, in an attempt to change their image, the German foundations lobbied the cabinets of the Commissioners in charge of external relations. Aiming to counter the criticism of partisanship, they created a politically diversified steering committee in i998. In order to overcome being labelled as purely national structures, foundations co-opted partners from other EU countries. This strategy of seeking access to the Commission has led to the strengthening of formal links between political foundations from different European countries.

\section{A First Step towards Recognition: Building Foundations Networks in Europe}

Knocking at the Commission's door, the political foundations have adopted the strategy of other interest groups seeking access and recognition at EU level (Coen 2007). As the Commission favours dialogue with strong and representative Eurogroups (Greenwood 2007), the foundations sought to build a transnational structure that would fulfil this requirement and demonstrate their independence from political parties. The collective action undertaken by the foundations' incipient networks shows that behind the apparently converging strategies, different ideas and worldviews compete with each other.

The co-operation of national political foundations at the European level stems from an informal international co-ordination of foundations active in the field of democracy promotion. The US invasion of Iraq reinforced the shared feeling that a common European strategy was necessary to offer an alternative to the military forms of imposing democracy. However, the issue became highly contested as soon as practical solutions were discussed. This first network of European foundations and institutes active in the development of co-operation was created in July 2004, at a conference on the European profile of democracy assistance, held in the Hague and organised by the Netherlands Institute for Multiparty Democracy (NIMD) during the Dutch presidency of the EU (Hague statement 2004, van Doorn and 
von Meijenfeldt 2007). In the EP, the network initiated by the NIMD cooperated with the European Democracy Caucus, an informal all-party group of MEPs set up in 2005 to promote democracy and human rights in the EU's neighbouring countries and chaired by Edward McMillan-Scott (Conservative UK, EPP-ED). At the request of the Democracy Caucus, David French, the director of the British Westminster Foundation for Democracy (WFD), and Roel von Meijenfeldt, the director of the NIMD, drafted a proposal to create a European Foundation for Democracy through Partnership (French, von Meijenfeldt and Youngs 2007). In the spring of 2006, when the NIMD published the proposal, the network split. The German political foundations were the main secessionists. They created an alternative European Network of Political Foundations (ENoP) in October 2006, inviting their partners to join.

This split unveils two incompatible perceptions of democracy promotion linked with different institutional traditions. According to the 'multi-party' vision - of the British and the Dutch experts - there is a single best way to promote democracy, based on a certain amount of procedural solutions, mainly electoral and constitutional engineering. The international programmes promoted by the NIMD and the WFD encourage inter-party co-operation by opening centres for multiparty democracy. These formal structures and informal beliefs influenced the strategy pursued by the NIMD network at EU level. The objective was to set up one EU-wide foundation, which would coordinate the activities of different national foundations in the field of democracy assistance and provide flexible funding.

This objective was perceived as a threat by the German political foundations and their close partners. Linked to one particular party, these organisations considered that the idea of a single, allencompassing foundation called into question their institutional rationale. Based on different normative beliefs, the German foundations prefer a sister-party approach. The main idea is that the prerequisite for establishing democracy is the existence of a robust political party system and party competition. This belief stems from the constitutional role of political parties in the Federal Republic of Germany. The strategy encouraging heterogeneous political foundations to promote similar political movements abroad has been qualified as a 'pluralist' approach by the German foundations, as opposed to the 'multi-party' approach. The ENoP was joined by French, Dutch, Austrian, Swedish, Greek, Spanish, and other single party foundations.

This case shows the importance of what Rhodes has called 'traditions', which inform diverse sets of beliefs about the public sphere, authority and power (Rhodes 2007). However, I argue that a dilemma 
linked to a political contest on the right way to reform governance does not necessarily 'push' the actors to reconsider their beliefs. In the short-term, rival positions may lead to a certain degree of compromise. However, if actors feel that their core beliefs (Sabatier 1998) and preferences are threatened, they may choose the 'exit' option and leave the network. The network initially launched by the NIMD was a loose issue, which did not manage to overcome the internal dilemmas, as they were related to competing core beliefs.

The ENoP is a technical network composed, as of 2008, of 48 political foundations from 2I European countries, with ideological ties to the five major party groups represented in the EP. It aims to lobby the European institutions, especially the Commission, to promote the integration of the political foundations in the EU programmes and provide a platform for dialogue (ENoP, April 2008). The $\mathrm{ENoP}$ is portrayed as a representative and politically pluralist body. It is clearly geared towards members that are 'close to but independent of a political party' (ENoP 2008), and are represented either in a national parliament or in the EP. Its transnational character notwithstanding, the composition of the ENoP's leading bodies shows the instrumental role initially played by the German foundations. Five out of nine representatives of major EP political groups in the first steering committee were German (4 out of 9 during the second term). During the first year of its existence, the network was coordinated by a representative of the Christian democratic Konrad Adenauer Foundation (KAS) and located in its office in Brussels. In 2007, the director of the liberal Friedrich Naumann Foundation (FNS) office in Brussels was entrusted with the co-ordination of the network.

The ENoP appears as a means to balance out the structural inequalities between the foundations. None of them enjoy the same resources as the German ones and many members of the network, especially those from the EU's new member states, have very limited resources. In the first years, the German foundations have entirely financed the network to enable the smaller foundations to participate in its activities. The network aims to ensure a transfer of expertise in order to empower its weaker members and assist them in accessing EU funds. However, it is clearly not a one-way relationship. To prove that they were not the only ones to push in favour of their recognition at EU level, the German political foundations needed to have other similar organisations joining them.

In the meantime, the NIMD network engaged in a vigorous campaign promoting the creation of a European multi-party foundation for democracy and mobilising the support of prominent politicians, such as Václav Havel, former president of the Czech Republic. The 
European Foundation for Democracy through Partnership was officially

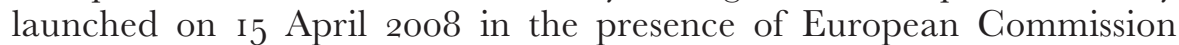
president, José Manuel Barroso. Renamed as the European Partnership for Democracy (EPD), a network of I $_{5}$ European democracy assistance organisations, the foundation aims to complement existing EU democracy assistance instruments. Both the ENoP and the EPD networks are in tune with the Commission's expectations of transnational policy networks. Both resembles an epistemic community, i.e. a knowledgebased network of individuals, which claims its authority on policyrelevant knowledge and professional standards (Haas i990). Whether these networks are likely to be accommodating, cooperate or compete requires further investigation.

\section{Towards the 2007 Regulation: Inter-institutional Bargaining and Political Entrepreneurship}

Building on the existing foundations' networks, the creation of European political foundations came under the co-decision procedure following the Commission's proposal to revise the existing regulation on European political parties in 2007. However, a closer analysis of the decision-making process leading to this new regulation provides evidence of the key role played by political entrepreneurs in the EP and the political foundations present in Brussels. This case is significant not so much for its financial impact, which remains limited in the first stage,${ }^{6}$ but to see how the Commission tackles a politically sensitive and unprecedented issue. It contributes to the analysis of the Commission's role as network broker (Borrás 2007). The Commission appears as a gate-keeper, not so much in network formation, but in network recognition at the EU level, ensuing access to policy-making and funding.

One of the key players in the creation of European political foundations was the EP Committee on Constitutional Affairs (AFCO) with its German Chairman Jo Leinen (PES), who was the rapporteur on the Commission's proposal (EP 2007). As an established figure of European institutional affairs, Leinen had supported the Regulation on European political parties, which was adopted in 2003. He was also a strong proponent of establishing political foundations at the European level. The Leinen report on the European political parties and a subsequent EP resolution issued in March 2006 have called on the Commission to find a way of financing European political foundations, which could complete the activities of Europarties in the field of information and education. After a long period of reluctance from the Commission, a window of opportunity opened at this moment. 
The official recognition of political foundations at EU level cannot be explained without taking into account the Commission's current preoccupation with strengthening the communication on European affairs. In the aftermath of the negative outcomes of the French and Dutch constitutional referendums in 2005, the Commission launched a 'Plan D' to promote democracy, dialogue and debate with European citizens. This initiative emerged at a time when an efficient communication policy had become a major priority of the Community institutions, aimed at generating '(mass) support, (citizen) consent and (electoral) participation)' (Aldrin, Utard, 2008: 3). The decision to enable the European political parties to organise transnational electoral campaigns and to create European political foundations appeared as an opportunity to stimulate public debate and citizen involvement. Faced with the challenge of communicating increasingly complex common policies to the public, the Commission officials perceived political foundations as a solution with the potential to involve citizens in the process of European integration. Technically, the establishment of direct contacts and constant dialogue between Leinen's office, the cabinet of the Commissioner Margot Wallström and the General Secretary of the Commission helped the project develop smoothly. As Vice President of the Commission in charge of Institutional Relations and Communication, Wallström strongly supported the project of creating European political foundations. Faced with renewed questioning of their legitimacy, Commission officials were open to innovative solutions which could help them to answer the public demand of more dialogue with the citizens.

Before the formulation of the Commission's proposal, a series of meetings was organised between Commission and EP representatives to deliberate on European political foundations. Concurrently, the relevant rapporteurs in the EP committees (AFCO, Budget) and the leaders of the main Europarties met with representatives of the national political foundations, who lobbied strongly on this issue. Due to their presence in Brussels, the German political foundations were those who spoke on behalf of their partners from other countries. The directors of the main foundations' Brussels offices - the KAS, the FES, the FNS and the Green Heinrich Böll Foundation (HBS) - played a key role in bringing information, organisational templates and arranging contacts with other foundation representatives. These directors were senior officials with experience of democracy promotion abroad and easy access to the European institutions, and thus they were considered as experts. The fact that the national foundations had already been assembled into a network was a helpful argument in favour of the universality of the foundations' model. The Leinen report explicitly 
cited the ENoP, stressing that 'political foundations linked to parties are a feature of many Member States, and cross-border co-operation between political foundations can already be seen in a number of forms' (EP 2007: II).

In its June 2007 proposal published after consultations with different stakeholders (the European political parties, but also the ENoP network), the Commission defined the 'political foundations at European level' as 'an entity or network of entities which has legal personality in a Member State, is affiliated with a political party at European level and which through its activities underpins and complements the objectives of the European political party by performing, in particular, the following tasks'. First, the European foundations were meant to analyse and contribute to the debate on the European integration process; secondly to organise conferences, training and studies on European issues; lastly, to serve as a framework for national political foundations, academics, and other relevant actors to work together at European level (European Commission 2007a). This definition is based on the recognition of the fact that 'political foundations already play an important role in national political systems' due to their capacity 'to undertake different and more long-term activities from political parties at European level' (European Commission 2007a: 4-5). This argumentation shows that referring to successful solutions at the national level is a way to justify transfer. Domestic institutions provide a type of 'anchor' for the mimetic isomorphism at EU level (Radaelli 2000).

The question here is whether the project to establish European political foundations can be considered as an uncontested issue in the EP. As it enabled the strengthening of resources and widening of the scope of action of the European political parties, most of the groups and parties supported the idea. However, there was a certain amount of debate and hesitation, especially in the European People's Party (EPP). The EPP already had several affiliated think tank networks and foundations, and there were divergences about how to accommodate these existing structures within the new foundation. A representative of the Party of European Socialists (PES) pushed in favour of including the political youth organizations as beneficiaries of the Regulation. However, the Commission rejected this proposal, as it was afraid of opening a breach for new claims. Finally, the leaders of the major European parties - the EPP, the PES, the European Liberal, Democrat and Reform Party (ELDR), and the European Green Party (EGP) promoted the issue during discussions with national political parties. Once the co-decision procedure was launched, these leaders also engaged in convincing members of the national governments to approve the proposal in the Council. 
After relatively smooth communication between the Commission and the political level of the EP, resistance came from the side of the Council. Despite concerns about the added value of the European political foundations, the main criticism did not address the provisions on the foundations, but the European political parties. It addressed the possible derogations of the Financial Regulation, especially from the non-profit rule, i.e. the possibility for the political parties to set aside reserves and to postpone the execution of their programme for three months of the following year. This criticism came mainly from the British, Dutch, German, Danish and Austrian representatives, but Finland, Sweden and Latvia also expressed some concerns. They were backed by the Council's legal service, which strongly criticised the proposal. ${ }^{7}$ Additionally, Ireland opposed the provisions on financing European election campaigns because of its national legislation. The Commission's secretary general tried to accommodate these arguments. Searching for a consensus, the EPP President, the Belgian Wilfried Martens, played a similar role as during the first regulation on Europarties by attempting to win the support of the national executives (Johansson and Raunio 2005). The opposition, which had to be overcome in the Council, confirms the fact that 'lesson-drawing is part of a contested political process' (Rose I993: 6).

\section{Setting up the European Political Foundations: a Constrained Policy Transfer}

Some institutional arrangements, which preceded and influenced the 2007 Regulation, allowed the launching of the first political foundations structures at the EU level. After some unsuccessful attempts, the political entrepreneurs promoting the idea of European political foundations in the EP convinced the Commission to launch a 'pilot project' to support the development of these foundations. The idea was to ensure a permanent funding mechanism for European political foundations, as the existing Regulation was under revision. After the EP had introduced a budget line to the 2007 EU budget, the execution of the pilot project was entrusted to the DG Education and Culture (DG EAC). Previously, personal contacts between Leinen's office and high-ranking representatives of the Commission (the Secretary General and Wallström's cabinet, but also the Cabinet of the Commission's President Barroso) had been crucial in the process.

The unprecedented project of setting up political foundations linked to the Europarties confronted the Commission's services with some dilemmas. The call for proposals of the DG EAC created a de facto monopoly situation, as the definition of applicants was very narrow, 
i.e. it was only addressed to the European political parties, explicitly named. The Commission's civil servants faced a politically sensitive problem, which was followed at the highest level of the Commission, and subject to the strong lobbying of the EP and of the national foundations. As evaluating the political content of Europarties' proposals concerning their new foundations appeared as a 'mission impossible' to the Commission's officials, they decided to share the available funding according to the rules established by the 2003 Regulation on European political parties. ${ }^{8}$ Consultations and meetings with the representatives of the European parties and of the national foundations were organised. As a result, the Commission agreed to guarantee a maximum of flexibility, allocating up to go per cent of the total financing to the new foundations and accepting contributions in kind. The pilot project reached the goal of stimulating the creation of Io European political foundations able to fit the rules set by the 2007 Regulation. The eagerness in implementing these legal provisions was linked to the perspective of the 2009 European elections, to which the European political parties and foundations are expected to contribute.

As of 2008, all Europarties have set up their foundations (see Table I). While the degree of proximity to the respective party varies, most of these foundations include representatives of the party, the political group in the EP and the national political foundations. While the co-ordination of their activities takes place in Brussels, most of their activities should be decentralised at EU member state level. The Regulation states that the foundations' governing bodies shall have a geographically balanced composition. However, the German expertise and resources were definitely instrumental in setting up these new structures. In most cases, the first secretary general or executive director of the main newly established European foundations is a German foundation representative. The President of the Liberal foundation, MEP Alexander Lambsdorff, is the son of the President of the German FNS, Count Otto Lambsdorff. The general secretary of the PES foundation is the director of the FES Brussels office, Ernst Stetter. The same logic operates for the Green Foundation. On the far left, the Transform! Network of Marxist, communist and socialist foundations launched by the German Rosa Luxemburg Foundation (RLS) was recognised by the European Left Party (EL) during the Prague Congress in November 2007 as its political foundation.

Due to the strong involvement of German MEPs and foundation representatives, is it possible to speak of a transfer of the German model of political foundations to the European level? The answer has to be nuanced. Policy transfer has been defined as a 'process by which knowledge about policies, administrative arrangements, institutions and 
Table I. The European political foundations (2008)

\begin{tabular}{|c|c|c|c|}
\hline $\begin{array}{l}\text { European } \\
\text { Foundation }\end{array}$ & $\begin{array}{l}\text { Affiliation to } \\
\text { European political } \\
\text { party }\end{array}$ & Decision-making bodies & $\begin{array}{c}\text { EU grants } \\
\text { September } 2007^{-} \\
\text {December } 2008(€)^{*}\end{array}$ \\
\hline $\begin{array}{l}\text { Centre for European } \\
\text { Studies (CES) }\end{array}$ & $\begin{array}{l}\text { European People's } \\
\text { Party (EPP) }\end{array}$ & $\begin{array}{l}\text { Board members: Wilfried } \\
\text { Martens, MEP (president) } \\
\text { Joseph Daul (MEP), Antonio } \\
\text { López-Istúriz (MEP), Peter } \\
\text { Weilemann (director of the } \\
\text { KAS Brussels office) } \\
\text { Secretary general: Tomi } \\
\text { Huhtanen (EPP) }\end{array}$ & І. 814.028 \\
\hline $\begin{array}{l}\text { Foundation for } \\
\text { European } \\
\text { Progressive Studies } \\
\text { (FEPS) }\end{array}$ & $\begin{array}{l}\text { Party of European } \\
\text { Socialists (PES) }\end{array}$ & $\begin{array}{l}\text { President: to be named } \\
\text { Vice-Presidents: Jesus Caldera } \\
\text { (PSOE, president of IDEAS } \\
\text { Foundation, Spain), Poul } \\
\text { Nyrup Rasmussen (PES, } \\
\text { Denmark) } \\
\text { Karl Duffek, Treasurer } \\
\text { (Director of the } \\
\text { Dr.-Karl-Renner Institute, } \\
\text { Austria) } \\
\text { Henri Nallet, President of the } \\
\text { Scientific Council (France) } \\
\text { Secretary general: Ernst Stetter } \\
\text { (director of the FES Brussels } \\
\text { office) }\end{array}$ & I.494.900 \\
\hline $\begin{array}{l}\text { European Liberal } \\
\text { Forum (ELF) }\end{array}$ & $\begin{array}{l}\text { European Liberal, } \\
\text { Democrat and } \\
\text { Reform Party } \\
\text { (ELDR) }\end{array}$ & $\begin{array}{l}\text { President: Alexander Graf } \\
\text { Lambsdorff (MEP); } \\
\text { Vice-President: Annemie } \\
\text { Neyts-Uyttebroeck (MEP) } \\
\text { Treasurer: Thierry Coosemans } \\
\text { (Gentre Jean Gol, Belgique) } \\
\text { Executive Director: Susanne } \\
\text { Hartig (former FNS Officer) }\end{array}$ & $34^{\mathrm{I} .660}$ \\
\hline $\begin{array}{l}\text { Green European } \\
\text { Institute (GEI) }\end{array}$ & $\begin{array}{l}\text { European Green } \\
\text { Party (EGP) }\end{array}$ & $\begin{array}{l}\text { Presidents of the board of } \\
\text { directors: Heidi Hautala } \\
\text { (Finnish MP, former MEP), } \\
\text { Pierre Jonckheer (MEP) } \\
\text { Secretary general: Claude } \\
\text { Weinber (director of the HBS } \\
\text { Brussels office) }\end{array}$ & $364 \cdot 128$ \\
\hline $\begin{array}{l}\text { Institute of } \\
\text { European } \\
\text { Democrats (IED) }\end{array}$ & $\begin{array}{l}\text { European } \\
\text { Democratic Party } \\
\text { (PDE) }\end{array}$ & $\begin{array}{l}\text { Directors: } \\
\text { President: Jean-Claude } \\
\text { Casanova (Frankreich) } \\
\text { CEO: Luca Bader (Margherita } \\
\text { Party, Italy) } \\
\text { Directors: Gorka Agirre } \\
\text { Arizmendi (Spain) } \\
\text { Vytautas Gapsys (Lithuania) }\end{array}$ & 284.520 \\
\hline
\end{tabular}


TABle i. Continued

\begin{tabular}{|c|c|c|c|}
\hline $\begin{array}{l}\text { European } \\
\text { Foundation }\end{array}$ & $\begin{array}{c}\text { Affiliation to } \\
\text { European political } \\
\text { party }\end{array}$ & Decision-making bodies & $\begin{array}{c}\text { EU grants } \\
\text { September } 2007^{-} \\
\text {December } 2008(€)^{*}\end{array}$ \\
\hline $\begin{array}{l}\text { transform! European } \\
\text { network for } \\
\text { alternative thinking } \\
\text { and political } \\
\text { dialogue }\end{array}$ & $\begin{array}{l}\text { European Left Party } \\
\text { (ELP) }\end{array}$ & $\begin{array}{l}\text { First legal representative: } \\
\text { Michael Brie (RLS) } \\
\text { Managing board: Ruurik Holm } \\
\text { (Left Forum, Finland), } \\
\text { Elisabeth Gauthier (Espaces } \\
\text { Marx, France), Haris Golemis } \\
\text { (Nikos Poulantzas Institute, } \\
\text { Greece) } \\
\text { Coordinator: Walter Baier } \\
\text { (former leader of the Austrian } \\
\text { Communist Party, KPÖ) }\end{array}$ & I96.400 \\
\hline $\begin{array}{l}\text { EUROPA - } \\
\text { osservatorio sulle } \\
\text { politiche dell'unione }\end{array}$ & $\begin{array}{l}\text { Alliance for Europe } \\
\text { of the Nations } \\
\text { (AEN) }\end{array}$ & $\begin{array}{l}\text { Gianluca Brancadoro, Rosario } \\
\text { Cancila et al. (Italy) }\end{array}$ & 281.800 \\
\hline $\begin{array}{l}\text { Fondation politique } \\
\text { européenne pour la } \\
\text { Démocratie (FPED) }\end{array}$ & $\begin{array}{l}\text { Alliance des } \\
\text { Démocrates } \\
\text { Indépendants en } \\
\text { Europe (ADIE) }\end{array}$ & & 226.746 \\
\hline $\begin{array}{l}\text { Foundation for } \\
\text { European } \\
\text { Democracy (FEUD) }\end{array}$ & $\begin{array}{l}\text { EU Democrats } \\
\text { (EUD) }\end{array}$ & $\begin{array}{l}\text { Board: } \\
\text { President: John Anthony } \\
\text { Coughlan (Irish National } \\
\text { Platform) } \\
\text { Vice-President: Jens-Peter } \\
\text { Bonde (MEP, Denmark) } \\
\text { Secretary: Pelle Christy } \\
\text { Geertsen (Denmark) } \\
\text { Treasurer: Karoly Lorant } \\
\text { (Hungary) }\end{array}$ & I26.06o \\
\hline $\begin{array}{l}\text { Centre Maurits } \\
\text { Coppieters (CMC) }\end{array}$ & $\begin{array}{l}\text { European Free } \\
\text { Alliance (EFA) }\end{array}$ & President: Frans-Jos Verdoodt & I27.888 \\
\hline
\end{tabular}

*EU grants from the pilot project and for 2008. Source: Author's information from the Commission and the EP.

ideas in one political system (past or present) is used in development of policies, administrative arrangements, institutions and ideas in another political system' (Dolowitz and Marsh 2000: 5). According to Dolowitz and Marsh (2000) it may be conceptualised as a continuum between lesson-drawing and direct imposition, and cannot be reduced to the complete adoption of a policy model. The European institutional system stimulates policy transfer as it is confronted with a deficit of legitimacy. To ensure this legitimacy, the Commission tends to copy existing organisational structures (Radaelli 2000). 
Clearly, the intellectual background of the analysed initiative and a large part of the mobilisation during the inter-institutional process leading to the 2007 Regulation has to do with the promotion of the German model. In no other European country do the political foundations have such a strong position in the political system. In the German political system, political party foundations act in at least three ways: firstly, as think tanks that deliberate on general values and specific policy concepts; secondly, as educators inter alia providing scholarships and training future elites; and, finally, as agents of external and development policies. The last mentioned element has not been included in the provisions of the Regulation $1524 / 2007$, even though some Council representatives, especially from the new EU member states, had expressed this will.

Without the lobbying of the political foundations backed by the mobilisation in the EP, this new proposal would not have come into being. However, by wishing to export this successful model to the supranational level, the entrepreneurs analysed here had to accommodate the legal and procedural constraints. The fact that the EG Treaty recognises - in Article igI - the crucial role played by political parties at the European level provided the legal basis for the 2003 Regulation on European political parties. Thus, the unique way to fit in the idea of developing European political foundations was to adhere to the existing Regulation while closely affiliating these foundations with the Europarties. As a result the European foundations have to submit their applications for funding through the political party at the European level they are linked with, even if a separate budget line is created. This close relationship between foundations and political parties is a major difference in comparison with the German case, where a formal separation is the rule. This is why the creation of European foundations may be qualified as a constrained policy transfer.

\section{Conclusion}

Considering networks as more than a metaphor, this article empirically reconsidered the changing relationship between the European institutions and the political foundations networks. The recent reorientation of the EU's external instruments and the Commission's efforts to improve communication on EU public policies have opened new perspectives for the structuring of the foundations' field. The experience of party affiliated foundations, gained in the context of democratisation and during EU enlargements, has allowed them to act as experts during consultations with Commission officials. Nevertheless, 
knowledge alone was not sufficient to counter the Commission's criticism of partisanship. This is why political foundations engaged in building networks like other interest groups before them. After the first foundations' network split due to diverging core beliefs, other structures emerged around more consensual institutional traditions. However, in both cases, horizontal co-operation does not exclude competition and power relations. The ability to speak in the name of other members of the network or to deliberate directly with the EP and Commission officials is a privilege available to a network's key players. Compared to other organisations, the German political foundations combine material and political resources and expertise, which optimise their access and leverage capacities in spreading the model of political foundations. However, the observed transfer is one that is incomplete and may lead to hybridisation.

The European political foundations are entrusted with carrying out classical think tank activities, such as research, debates and also similar to the German case - political training. However, as the European foundations are transnational by definition, they may combine different traditions of political counsel and strategic policy analysis. According to Diane Stone (2000), think tanks may become agents of policy transfer as they enable elite networking and information sharing - through regular interaction during the agenda-setting and policy formulation stages - and provide scholarly discourse to legitimise certain policy options. Against this background, the idea to stimulate public debate and to link party politicians and experts to a wider public illustrates the willingness of European leaders to better explain and legitimise European policy-making through political party channels. As far as the international activities are concerned, the European foundations' capacities are limited. They can act as advocates of democracy, 'developing co-operation with entities of the same kind' (Regulation (EC) I524/2007) and bringing together national political foundations and academics at the European level.

European political foundations are innovative types of transnational bodies, as they are meant to link representatives of political parties, political groups, youth movements and national foundations. The potential policy impact of these organisations is difficult to measure since their definitive form and role remains to be clarified. The political will expressed at the highest level of the Commission to institutionalise these political think tanks may be a sign of a new consideration of party-related policy analysis in EU policy-making, further closing the gap between European politics and policies by politicising policy transfer. For some authors, increasing party competition at the EU level could be a panacea for the 'democratic deficit' (Hix 2008). 
However, European political foundations are more eclectic and fragile organisations than European political parties. Therefore, they currently seem unlikely to decisively shape the European polity, even if they may contribute to elaborating common positions on EU policies. Whether the European foundations will engage in a broader public debate, without limiting themselves to 'preaching to the converted' or acting as supplementary socialisation arenas for party youth organisations, remains an open question. As with other EU-level representation and coordination bodies, what is at stake for the European foundations is to find the right balance between a Brussels-based agenda-setting activity and a means of communicating with broader domestic constituencies.

\section{NOTES}

I. I would like to thank Wolfram Kaiser and the anonymous referees for their stimulating comments on the former versions of this article, as well as Jean-Yves Bart for his thorough linguistic revision.

2. Focusing on the transnational diffusion of the political foundations, and their implementation at the EU level, I use the term of political foundation to refer to politically oriented associations and think tanks. However this broad definition may encompass more or less closely party affiliated organizations.

3. Regulation 2004/2003 institutionalised 'political parties at European level', providing them with a statute and EU funding.

4. The existing associations oscillate between the defence of public interests and political activism. Large Europarties can be linked with associations representing elderly people, workers, business organizations or sexual minorities.

5. Between September 2007 and December 2008, 26 individuals were interviewed in Brussels, Paris, Amsterdam, Berlin and The Hague, representing the political foundations and think tanks at the national and European levels (Dutch, French, German foundations active in Brussels, representatives of the main European foundation networks, as well as representatives of the main European political foundations), the European Commission (Secretary General, DG Education and Culture), and the European Parliament (DG Finance, as well as the main political groups and Europarties). These interviews focused on the process of the creation of European political foundations, its origins, stages, actors involved on different sides, as well as the expected impact. Questions were also asked about the structuring of the national foundations' networks at the EU level. Previously, during my $\mathrm{PhD}$ research on the German political foundations, I interviewed more than Ioo representatives in Germany, Brussels, Warsaw and Budapest, from the political foundations and their partners abroad, the German and Polish parties and parliamentary groups, as well as the federal ministries. To guarantee the anonymity of the interviewees, these interviews will not be cited.

6. On the basis of the 2007 Regulation, European political parties received $€_{\mathrm{IO}} .6$ million from the EU budget in 2008 ( $€_{\mathrm{IO}} .2$ million in 2007, $€_{\mathrm{IO}} .8$ million expected in 2009). European political foundations received $€_{5}$ million (September-December 2008). Before, the European foundations received $€_{\mathrm{I}}$ million from the pilot project launched by the Commission (September 2007-August 2008). They are expected to get $€_{7}$ million in EU grants in 2009. These grants are comparable to the budgets of the small national political foundations but are insignificant compared to the German foundations' budgets, of which the smallest, the Rosa-Luxemburg-Stiftung (RLS), alone received more than $€_{\mathrm{I} 7}$ million from federal grants in 2007 . EU grants make up 85 per cent of European parties' and foundations' total budgets (see table I).

7. Finally, the proposal led to the adoption of two separate regulations: Regulation $1524 / 2007$ revising the 2003 Regulation on European political parties and Regulation I525/2007 revising the Financial Regulation applicable to the general budget of the EU, softening the non-profit rule of European party financing. This split was heavily criticized by the EP President Hans-Gert 
Pöttering, the MEP Leinen and the Commissioner Wallström during the EP plenary session on 25 October 2007.

8. This means that 15 per cent is distributed in equal shares and 85 per cent is divided proportionally in accordance with the number of elected MEPs.

\section{REFERENCES}

Abélès M. and Bellier I. (1996) La Commission européenne: du compromis culturel à la culture politique du compromis, Revue française de science politique, 46, 3, 43-456.

Aldrin P. and Utard J-M. (2008), The ambivalent politicisation of European communication. Genesis of the controversies and institutional frictions surrounding the 2006 White Paper. GSPE Working Papers, Io/28/2008, http://workingpapers.gspe.eu

Bartsch S. (1998) Politische Stiftungen: Grenzgänger zwischen Staaten- und Gesellschaftswelt, in: W.-D. Eberwein and K. Kaiser (eds.), Deutschlands Neue Außenpolitik. Munich: Oldenburg, 185-198.

Borrás S. (2007) The European Commission as Network Broker, European Integration online Papers (EIoP) II, I, http://eiop.or.at/eiop/texte/2007-oora.htm

Bourdieu P. (I98I) La représentation politique. Eléments pour une théorie du champ politique, Actes de la Recherche en Sciences Sociales, 36-37, 3-24.

Bouwen P. (2002) Corporate Lobbying in the European Union: the Logic of Access, fournal of European Public Policy, 9, 3, 365-390.

Coen D. (2007) Empirical and Theoretical Studies in EU Lobbying, Fournal of European Public Policy, I4, 3, 333-345.

Dakowska D. (2005a) Die Arbeit der Friedrich-Ebert-Stiftung in Polen zwischen 1971 und der friedlichen Revolution, Archiv fü Sozialgeschichte, 45, 325-352.

Dakowska D. (2005b) German Political Foundations: Transnational Party Go-betweens in the Process of EU Enlargement. In W. Kaiser and P. Starie (eds.), Transnational European Union. Towards a Common Political Space. London: Routledge, I50-169.

Dakowska D. (2009) Networking of Political Foundations: The Catalytic Effects of Transition and the European Union's Eastern Enlargement. In W. Kaiser, M. Gehler and B. Leucht (eds.), Networks in European Multi-Level Governance. From 1945 to the Present. Vienna: Böhlau.

De Waele J-M. and Delwit P. (eds.) (1998) La Démocratisation en Europe centrale. La coopération paneuropéenne des partis politiques. Paris: L'Harmattan.

Delwit P., Külahci E. and Van de Walle C. (eds.) (200I) Les fédérations européennes des partis. Organisation et influence. Bruxelles: Editions de l'ULB.

DiMaggio P. and Powell W. W. (eds.) (I99I) The New Institutionalism in Organizational Analysis. Chicago: University of Chicago Press.

Dolowitz D. and Marsh D. (2000), Who learns from whom. A Review of the Policy Transfer Literature, Political Studies, 44, 343-357.

Dolowitz D. and Marsh D. (2000) Learning from Abroad: The Role of Policy Transfer in Contemporary Policy Making, Governance, I3, I, 5-24.

Dür A. and De Bièvre D. (2007) Inclusion without Influence? NGOs in European Trade Policy, Journal of Public Policy, 27, I, 79-101.

Eising R. (2007) The access of business interests to EU institutions: towards élite pluralism?, fournal of European Public Policy, I4, 3, 384-403.

European Network of Political Foundations (April 2008), About ENoP. Unpublished document.

European Commission, (27. 6. 2007a), COM (2007) 364 final, 2007/or3o (COD). Proposal for a Regulation of the European Parliament and of the Council amending Regulation (EC) No $2004 / 2003$ on the regulations governing political parties at European level and the rules regarding their funding (presented by the Commission).

European Commission (27. 6. 2007b) press release IP/o7/949, Strengthening European Democracy, political debate and voter participation in elections to the European Parliament. Brussels, http://europa.eu/rapid/pressReleasesAction.do?reference=IP/o7/949\&format=HTML\&aged= I\&language $=$ EN\&guiLanguage $=$ en $($ accessed i October 2008)

European Parliament, Committee on Constitutional Affairs, (2007), Draft report on the proposal for a regulation of the European Parliament and of the Council amending Regulation (EC) No $2004 / 2003$ on the regulations governing political parties at European level and the rules regarding their funding $(\mathrm{COM}(2007) 0364-\mathrm{C} 6-0202 / 2007$ - 2007/o13o(COD)), 24.7.2007, Rapporteur: Jo Leinen. 
French D., von Meijenfeldt R. R. and Youngs R (2007) A European Foundation for Democracy. Enhancing the European Profile of Democracy Assistance, March 2007 (updated version, unpublished paper).

Green Cowles M. (I996) The EU Committee of Am Cham: the powerful voice of American firms in Brussels, Fournal of European Public Policy, 3, 3, 339-358.

Greenwood J. (2007) Interest Representation in the European Union. 2nd ed., London: Palgrave.

Hass P. M. (1992) Introduction: epistemic communities and international policy coordination, International Organization, 46, I, I-35.

(The) Hague Statement on Enhancing the European profile of democracy assistance (2004), The Hague.

Hall P. and Taylor R. (I996) Political Science and the Three New Institutionalisms, Political Studies, 44, 5, 936-957.

Hix S. (I995) Parties at the European Level and the Legitimacy of EU Socio-Economic Policy, Fournal of Common Market Studies, 33, 4, 527-554.

Hix S. and Lord C. (I997) Political parties in the European Union. Basingstoke: Macmillan.

Hix S. (2008) What's Wrong With the European Union and How to Fix It?. London: Polity Press.

Joana J. and Smith A. (2002) Les commissaires européens. Technocrates, diplomates ou politiques? Paris: Presses de Sciences Po.

Johansson K. M. (1997) Transnational Party Alliances. Analysing the Hard-Won Alliance between Conservatives and Christian-Democrats in the European Parliament. Lund: Lund University Press.

Johansson K. M. and Raunio T. (2005) Regulating Europarties: Cross-Party Coalitions Capitalizing on Incomplete Contracts. Party Politics, II, 5, 515-534.

Kohler-Koch B. and Eising R. (eds.) (I999) The Transformation of Governance in the European Union. London: Routledge.

Mayntz R. (I993) Policy-Netzwerke und die Logik von Verhandlungssystemen, Politische Vierteljahresschrift, $24,39^{-5} 6$.

Mayntz R. and Scharpf F. W. (200I) L'institutionnalisme centré sur les acteurs, Politix, I4, 55, $95^{-\mathrm{I} 23}$.

Mazey S. and Richardson J. J. (1993) Lobbying in the European Community. Oxford: Oxford University Press.

Ortuño Anaya P. (2002) European Socialists and Spain: the Transition to Democracy. Basingstoke: Palgrave.

Pappi F. U. and H. C. A. Henning (1998) Policy Networks: More than a Metaphor?, Journal of Theoretical Politics, Io, 4, 553-575.

Phillips A. L. (I999) Exporting Democracy: German Political Foundations in Central-East Europe, Democratization 6, 2, 70-98.

Pinto-Duschinsky M. (I996) International Political Finance: The Konrad Adenauer Foundation and Latin America. In: L. Whitehead (ed.), The International Dimension of Democratization. Europe and the Americas. Oxford: OUP, 227-255.

Radaelli C. (200o) Policy Transfer in the European Union: Institutional Isomorphism as a Source of Legitimacy, Governance, I3, I, 25-43.

Radaelli C. (2005) Diffusion without convergence: how political context shapes the adoption of regulatory impact assessment, Fournal of European Public Policy, i2, 5, 924-943.

Regulation (EC) No I524/2007 of the European Parliament and of the Council (I8 December 2007) amending Regulation (EC) No $2004 / 2003$ on the regulations governing political parties at European level and the rules regarding their funding.

Rhodes R. A. W. (2003) Putting People Back into Networks, Australian Fournal of Political Science, 37 , 3, 399-4I6.

Rhodes R. A. W. (2007) Understanding Governance: Ten Years On, Organization Studies, 28, 8, I $243-\mathrm{I} 264$.

Rose R. (I99I) What is Lesson-Drawing?, Fournal of Public Policy, II, I, 3-3o.

Rose R. (I993) Lesson-Drawing in Public Policy. Chatham, NJ: Chatham House.

Sabatier P. A. (1998) The Advocacy Coalition Framework. Revisions and Relevance for Europe, Journal of European Public Policy, 5, I, 98-izo.

Saurugger S. (200I) A fragmented environment: interest groups and the Commission's bureaucratic sectorisation, Politique européenne, 5, 45-69.

Smith A. (ed.) (2004) Politics and the European Commission. Actors, Interdependence, Legitimacy. London: Routledge.

Stone D. (2000) Non-governmental Policy Transfer: The strategies of Independent Policy Institutes, Governance, I3, I, 45-62. 
van Doorn M. and von Meijenfeldt R. (eds.) (2007) Democracy, Europe's Core Value? On the European Profile in World-wide Democracy Assistance. Delft: Eburon.

Wagner C. (I994) Die offiziöse Außen- und Entwicklungspolitik der deutschen politischen Stiftungen in Lateinamerika. In: M. Mols and C. Wagner (eds.), Deutschland - Lateinamerika. Geschichte, Gegenwart und Perspektiven. Frankfurt a.M.: Verwuert Verlag.

Weisbein J. (2003) Sociogenèse de la « société civile européenne », Raisons politiques, 5-7, Io, I25-I37.

DR. DOROTA DAKOWSKA

Institut d'Etudes Politiques

Groupe de Sociologie Politique Européenne

47, avenue de la Forêt Noire

67082 Strasbourg, France

e-mail:dorota.dakowska@misha.fr 